\title{
Effect of Cyber Counseling on Increasing Self- Actualization of High-School Students in Buleleng, Bali
}

\author{
Ni Ketut Suarni ${ }^{1}$, I Ketut Dharsana ${ }^{2}$, Gede Nugraha Sudarsana ${ }^{3}$ \\ \{niketut.suarni@undiksha.ac.id ${ }^{1}$,iketut.dharsana@undiksha.ac.id², playgede@gmail.com ${ }^{3}$ \} \\ Universitas Pendidikan Ganesha, Indonesia ${ }^{123}$
}

\begin{abstract}
This study aims to determine the differences in influence between cyber counseling and face-to-face counseling on improving self-actualization of high-school students in Buleleng, Bali. This type of research is quasi-experimental research and uses post-test only control group design. The research respondents were 85 high-school students in Buleleng, Bali, which were determined by random sampling techniques, and data collection using questionnaires and interviews. The results showed: 1) there were differences between the effect of cyber counseling and the effect of face-to-face counseling intervention on self-actualization of high-school students, obtained $\mathrm{F}=3.055$; 2) cyber counseling interventions are more effective than face-to-face counseling interventions for increasing self-actualization of high-school students in Buleleng, Bali with at-Scheffe value $=2.01$. Based on the results of the study, it can be concluded that cyber counseling increases self-actualization of high-school students in Buleleng, Bali.
\end{abstract}

Keywords: cyber counseling, face-to-face counseling, self-actualization.

\section{Introduction}

Education is a platform to develop students' self-potential, both in academic and nonacademic fields. Every human being is born with their own - unique and achievable. This suggests that the potential in humans still needs guidance in order to develop and meet every level of human needs. Self-potential does not automatically develop with age. Through education, students are guided to be able to develop their potential and fulfill their needs. As explained by Maslow, in life, there are several levels of fulfillment of human needs, so that eventually one can achieve self-actualization as a manifestation of his existence.

The utilization of self-potential is likened by Maslow as a process of fulfilling human needs to actualize themselves. In line with this statement, in the world of education according to Law No. 20 of 2003 articles 1 point 4, students are community members who try to develop their own potential through the learning process that is available on certain paths, levels and types of education. This is so that educators are responsible for developing the potential possessed by students as a form of self-actualization.

In the development of his theory, Maslow stated that self-actualization can be fulfilled by individuals in adolescence and those who have reached the early adult phase. The period is in 
the category of self-actualization, but in the development of the next theory, Maslow also explained that this self-actualization was not rigid. The purpose of the theory is that humans will not gradually fulfill their hierarchy of needs if there are more important needs to be fulfilled [1], [2]. This is relevant to this study to be able to develop self-actualization of high-school students in their teens.

Teenagers that are in the development period always try to experiment with new things and not close themselves to the development of the time. This is the case as it is the time when technology is one of the means of developing the potential of adolescents. The educator must be more sophisticated in terms of technology to be able to direct students to meet each of their growth needs. Not infrequently, teenagers demonstrate the development of their potential through the use of technology as a form of their actualization [3]. On the other hand, often, there are also teenagers that find it difficult to develop the potential in themselves due to several factors from within or outside themselves. During the period of growth and development, adolescents often find hesitation to be able to recognize the strengths and weaknesses that exist in them. In addition, the lack of support from the surrounding environment often makes it difficult for teens to develop their potential. This causes an obstruction in adolescents fulfilling their self-needs in order to achieve self-actualization [4].

The method that can be used as an effort to develop self-actualization is guidance and counseling intervention. Guidance tends to be preventive, while counseling tends to be curative or problem-solving services, which are executed more face-to-face between counselors and clients [5]. Conventionally, guidance and counseling are often given in the form of direct services or face-to-face counseling. Just as in schools, these services are often given in the form of classical guidance services, role play, and the like. In their implementation, it is not uncommon for a discussion of self-actualization to be overlooked. This requires more attention by educators to know every obstacle to the development of their students. The older the age, the more complex the problems faced. Like Bali, as a tourism destination city, there are often complex problems that arise in meeting the needs of everyone, caused by the rapid development of technology. With the existence of guidance and counseling services in schools, it is hoped that this can still help students to fulfill their actualization needs.

Knowing your own shortcomings and strengths is a person's capital to develop his or her potential as a form of actualization. However, self-actualization is still rarely discussed by guidance and counseling teachers due to several factors such as lack of hours providing services, monotonous or less attractive service delivery, and the density of student learning time at school. As a technology literate educator, it is necessary to take into account the use of technology in providing these services. In addition to paying attention to the growth and development of students physically, educators also need to pay attention to the psychological needs of students to be able to fulfill their human needs as explained by Maslow in the pyramid of needs hierarchy. One solution to this problem is the development of providing guidance and counseling services online, more commonly known as cyber counseling. Aside from being an intervention in developing self-actualization, cyber counseling also facilitates students who have intensive study time at school to the extent that it is impossible to conduct face-to-face counseling, as well as those who have an introverted nature, so that they can manage time to utilize counseling services through cyber counseling. 
This is in line with the results of research on self-actualization, that there is a positive relationship between self-actualization and the intensity of the use of social media paths, so the higher the self-actualization, the higher the intensity of the use of social media paths in adolescents in Banjarbaru 2 Senior High School [6]. In this sophisticated era, nothing will be far from using technology. Especially as adolescents in high school tend to have more interest in technology, it is used both as a communication and a game tool. As a fulfillment of needs and adjustments to the development of the times, it is very potent if the development of self-potential as a form of self-actualization can be done through the use of technology.

In further research conducted by Michael Shernoff regarding the use of cyber counseling for practical clinics, Michael described how the use of the internet can improve clinical practice as a forum that can support clients in recognizing their identity. It then facilitates interaction and communication between therapist and client, the provision of public education regarding mental health, and the provision of referrals to similar professionals [7]. This illustrates the use of technology as a forum to help counselees recognize their identity and not to worry about conveying their complaints because identity is kept confidential. Besides that, it is an alternative spread of education.

Through counseling in schools, there are also many studies that try to package the development of potential students but have not found guidance and counseling services either online or face-to-face to develop self-actualization needs. There are several articles that try to develop online counseling on willingness variables in students to use these programs in schools either face-to-face or with internet media, the results of which are that students are not interested in conducting counseling activities through either of these methods. This may be due to students assuming that the development of potential is only in the form of learning outcomes, whereas, in fact, to support learning outcomes, there are many types of potentials that need to be developed, one of which is self-actualization. Based on the results of the study of the article, the researcher views it very important to carry out an experiment to develop the potential for selfactualization through online counseling services.

The use of technology in counseling is actually not new because Prof. John Suler created another branch of science in the field of psychology, namely cyber psychology. He found a significant way to overcome internet addiction using technology. By developing psychology, automatically, it will also have an impact on the development of counseling. Technology-based counseling is a necessity to answer and meet people's needs related to alleviating quite complex problems in this modern era. As explained by Shannon D. Smith and Cynthia Reynolds, cybertherapy is a rapidly developing phenomenon, which causes the routine development of the internet to continue. The internet is considered as the right medium to provide various psychotherapy services [8].

In counseling services, the use of this technology is better known as cyber counseling. This type of counseling is used as a medium of interaction between counselors and counselees through technology without having to meet face to face. Cyber counseling is a form of using technology to help resolve counselee problems psychologically [9]. It's existence is also the answer to meeting human needs in order to make it easier to live their lives without having to encounter problems with these technologies. For example, someone who is experiencing 
dependence on technology which is causing problems in running his life, tends to find it difficult to seek outside help. With this media, it is hoped that it will be a good tool for overcoming problems without having to meet face to face. Applying cyber counseling to meet one's selfactualization is predicted to have significant potential success because currently there are still few people who have the application and use it, specifically in the field of counseling. This is the background of the researchers who want to find out how much influence the success of cyber counseling has on students' self-actualization needs compared to the use of face-to-face counseling.

\section{Methods}

\subsection{Experimental Design}

This type of research is a quasi-experimental study, with a post-test only control group design. The study population was as many as 150 high-school students in Buleleng, Bali, which was determined by random sampling techniques. The study sample was comprised of 85 students. In this experiment, the first group was given a cyber counseling technique - the group that would be given counseling services via the internet. While the second group was given faceto-face counseling techniques.

\subsection{Instrumentation}

The method of collecting data in this experiment is the use of Self-Actualization Scale of the Need Assessment (SASNA) questionnaire. The self-actualization questionnaire consists of 36 statements with SASNA scale choices that move from 1 to 8 . In calculating validity, the contents of the self-actualization questionnaire are used in Lawshe Formula [10]. Based on the calculation of the Content Validity Ratio (CVR) and the Content Validity Index (CVI), the questionnaire meets good requirements, so it can proceed to the next stage. In addition, the questionnaire fulfills valid and reliability requirements so that it can be used to collect research data.

\subsection{Data Analysis}

The hypotheses in this study were tested by analysis of one-way variants (ANOVA A), and they are 1) there are differences between the influences of cyber counseling and face-to-face counseling interventions on self-actualization of high-school students; 2) cyber counseling interventions are more effective than face-to-face counseling interventions in improving self- 
actualization of high-school students in Buleleng, Bali. The datasets of this research can be accessed at https://osf.io/j4ksx/ from the Open Science Frameworks.

\section{Results and Discussion}

The results showed that there were differences in the effects on self-actualization of highschool students who were counseled using cyber counseling and those counseled face-to-face. The results of hypothesis testing are presented in table 1 .

Table 1. Hypothesis Test Results

\begin{tabular}{lrrrrr}
\hline self-actualization & Sum of Squares & Df & Mean Square & F & Sig. \\
\hline Between Groups & 1224.816 & 2 & 612.408 & 3.055 & .053 \\
Within Groups & 16440.431 & 82 & 200.493 & & \\
Total & 17665.247 & 84 & & & \\
& & & & & \\
\hline
\end{tabular}

Obtained $F$ value $=3.055$ significance 0.05 . The hypothesis states that there are differences between the effects on self-actualization of high-school students who used cyber counseling and those who used face-to-face counseling. This shows that cyber counseling has a significant effect compared to face-to-face counseling in developing student self-actualization.

Next, finding out which of these interventions has the highest influence can be calculated in the following way:

$$
t_{1-2}=\frac{188.04-182.67}{\sqrt{200.493 x\left(\frac{1}{28}+\frac{1}{27}\right)}}=2.01
$$

Counseling intervention with the value of $\mathrm{t}-\mathrm{Scheffe}=2.01$. So, it can be concluded that cyber counseling interventions have more influence on the self-actualization of high-school students in Buleleng, Bali.

The results of this study also support a number of previous significant research findings that try to use technology media. In addition to the results of statistical analysis of factual and empirical data sources, based on researchers' observations and input from respondents, additional data that researchers can submit as a discussion of the results of this study are: Cyber counseling intervention provides the most effective influence in increasing self-actualization needs compared to face-to-face counseling interventions. On the positive side, it can be learned 
that there are things that are personal to clients who feel comfortable, and because of their confidentiality and prestige, they are protected. Client communication is not limited to spacing and time, if the client just wants to get confirmation or reinforcement from the counselor regarding the decision taken, which is "correct," cyber counseling interventions will provide more contributive benefits. This is in line with the findings of Faye Mishna et al. that cyber counseling is a trend that is favored by counselees and is expected to continue in the coming year [11]. In terms of weakness, it requires the willingness of the counselor to carry out services outside of school hours, increase learning motivation for counselors in developing knowledge and understanding of technological advances, and their use and development of innovative service models.

\section{Conclusions}

Based on the research findings obtained: 1) there are differences in the effects between cyber counseling and face-to-face counseling on self-actualization of high school students and obtained $\mathrm{F}=3.055 ; 2$ ) cyber counseling intervention is more effective than face-to-face counseling in increasing self-actualization of high-school students in Buleleng, Bali, with a value of $\mathrm{t}$-Scheffe $=2.01$. Based on these findings, it was concluded that cyber counseling increased self-actualization of these high school students. It is expected that technology-based counseling will become one of the alternatives for the implementation of guidance and counseling services in schools.

\section{References}

[1] L. Hall, "Self-actualization Psychology: The Positive Psychology of Human Nature's Bright Side,” Neuro-Semantics Publ., 2008.

[2] E. D. M. Priyadi, "Kajian Teori Maslow terhadap Motivasi Menjadi Guru Sekolah Minggu di Gereja Kristen Jawa Tangerang,” Universitas Kristen Satya Wacana, 2017.

[3] Atik Catur Budiati, “Aktualisasi Diri Perempuan Dalam Sistem Budaya Jawa (Persepsi Perempuan terhadap Nilai-nilai Budaya Jawa dalam Mengaktualisasikan Diri)," Pamator, vol. 3 Nomor 1, no. 271, pp. 51-59, 2010.

[4] V. K. Sari, "Pengaruh Penyesuaian Diri terhadap Aktualisasi Diri Remaja Di Lembaga Permasyarakatan Anak Blitar,” Psikovidya, vol. 17, no. 1, pp. 20-39, 2017.

[5] R. W. Astuti, M. Nursalim, T. I. Pratiwi, and W. Nuryono, "Implementation Guidance and Counselling for Changing Negative Perceptions of Students in High School in The District Lamongan,” Bk Unesa, vol. 3, no. 1, pp. 271-280, 2013.

[6] M. D. Putri, R. A., Erlyani, N., \& Mayangsari, "Hubungan antara Aktualisasi Diri dengan Intensitas Penggunaan Media Sosial Path pada Remaja di Sekolah Menengah Atas Negeri 2 Banjarbaru," Ecopsy, vol. 3, no. 1, pp. 1-7, 2016.

[7] M. Shernoff, "Cyber Counseling for Queer Clients and Clinicians: PRACTICE 
NOTES,” J. Gay Lesbian Soc. Serv., vol. 11, no. 4, pp. 105-111, Oct. 2000.

[8] Shannon D. Smith \& Cynthia Reynolds, "Cyber-psychotherapy," Ann. Am. Psychother. Assoc., vol. 5, no. 2, pp. 20-23, 2002.

[9] Ifdil dan Zadrian Ardi, "Konseling Online Sebagai Salah Satu Bentuk Pelayanan EKonseling," J. Konseling dan Pendidik., vol. 1, no. 1, pp. 15-21, 2013.

[10] S. Azwar, Konstruksi tes kemampuan kognitif. Yogyakarta: Pustaka Pelajar, 2016.

[11] F. Mishna, M. Bogo, and J. L. Sawyer, "Cyber Counseling: Illuminating Benefits and Challenges," Clin. Soc. Work J., vol. 43, no. 2, pp. 169-178, 2015. 